\title{
A Novel Cyclohexapeptidic Receptor for Peptides
}

\author{
In Whan Bae, Chang-Yeon Lee, Kum Hee Lee, and Seung Soo Yoon*
}

\author{
Department of Chemistry, SungKyunKwan University, Suwon 440-746, Korea. *E-mail: ssyoon@chem.skku.ac.kr \\ Received December 31, 2005
}

Key Words : Molecular recognition, Receptor, Supramolecular chemistry

Recently, macrocyclic peptides are recognized as the emerging class of new synthetic receptors for the various substrates. ${ }^{1}$ For example, a cyclopeptide such as cyclo(ProGly) ${ }_{3}$ and cyclo(Pro-Gly) ${ }_{4}$ were found to bind selectively with zwitterionic amino acid salts and amines. ${ }^{2}$ Also cyclopeptidic receptor were found to bind with anions such as phosphates and sulfates, and neutral peptides selectively. ${ }^{3}$ Furthermore, certain cyclopeptide such as cyclo[(L-Gln-DAla-L-Glu-D-Ala) $)_{2}$ ] was found to form peptide nanotube and thus act as selective ion channel. ${ }^{4}$

Particularly, cyclohexapeptides constitute interesting structural building blocks for novel synthetic receptors because these are reasonably expected to be conformationally homogeneous due to intramolecular hydrogen bonds such as proline-induced $\beta$-turn found in many protein secondary structures. ${ }^{5}$ Through connecting several cyclohexapeptides with the suitable spacer groups, it is possible to form the potential peptide-binding cavity surrounded by a number of well-defined, convergent hyrogen bonding donor/acceptors (-NHCO-) and the other functionalities derived from the side chain of amino acid in cyclohexapeptides as seen in many natural proteins. Furthermore, relatively easy access to the various cyclohexapeptides and spacer molecules make it possible the fine-tunning of structural and electronical properties of the cavity and thus binding properties of synthetic receptors.

Here, to explore the possibility of cyclohexapeptides as synthetic receptors, synthesis and peptide-binding properties of a novel cyclohexapeptidic receptor (1) is described.

Synthetic pathway for $\mathbf{1}$ is depicted in Scheme 2. Ester hydrolysis using 1 eq. $\mathrm{NaOH}$ and subsequent EDC coupling with pentafluorophenol furnished the tripeptide monoactivated ester intermediate for cyclohexapeptide. Macrocyclization was then carried out as a double amide formation by syringe pump addition of TFA salt of the mono-activated ester of 2. This cyclization provided monocyclic hexapeptide in $78 \%$ yield. Subsequent ester hydrolysis using 2 eq. $\mathrm{NaOH}$ and subsequent EDC coupling with pentafluorophenol furnished the bis-activated ester intermediate of cyclohexapeptide (3), and subsequent macrocyclization with the dye-linked di-TFA (4) under the high dilution condition provided receptor 1 with $32 \%$ yield. The structure of 1 was established by mass spectrometry and ${ }^{1} \mathrm{H}-\mathrm{NMR}$ spectroscopy.

Macrocyclic compound (1) has the well-defined, potential

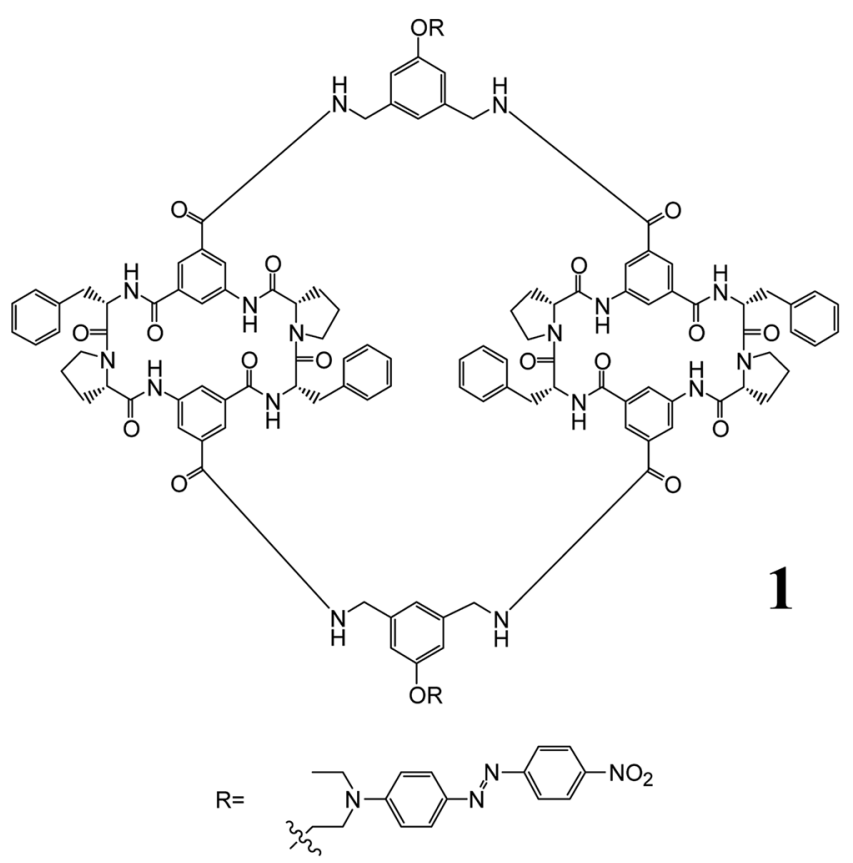

Scheme 1. Cyclohexapeptidic Receptor (1).

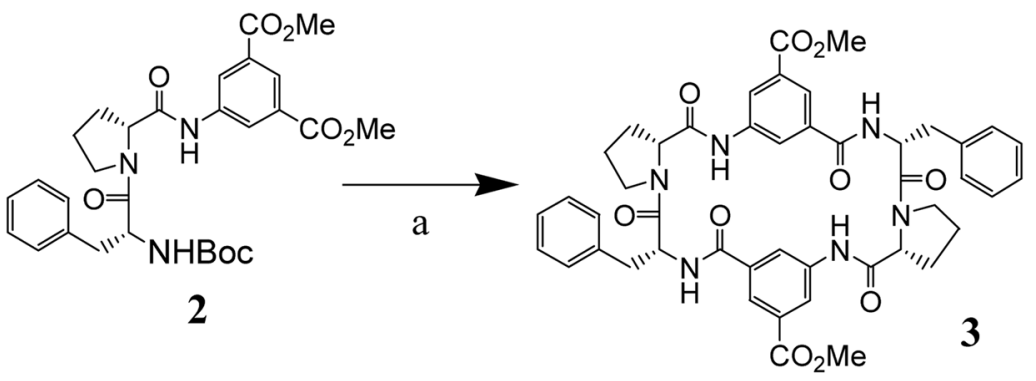

b

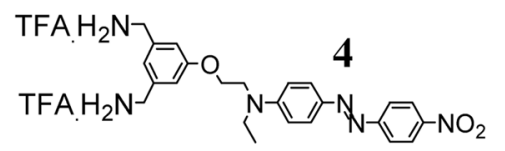

Scheme 2. Synthesis of Cyclohexapeptidic Receptor (1). (a) 1) $\mathrm{NaOH}$, then $\mathrm{C}_{6} \mathrm{~F}_{5} \mathrm{OH} \cdot \mathrm{EDC}$, 2) TFA, then slow addition to $i \mathrm{Pr}_{2} \mathrm{NEt} / \mathrm{THF}$, (b) 1) $\mathrm{NaOH}$, then $\left.\mathrm{C}_{6} \mathrm{~F}_{5} \mathrm{OH} \cdot \mathrm{EDC}, 2\right)$ slow addition to $i \mathrm{Pr}_{2} \mathrm{NEt} / \mathrm{THF}$ with 4. 
Table 1. Sequence of tripeptides selected by binding assay with receptor (1)

\begin{tabular}{clcl}
\hline 1 & (L)Leu-(L)Gln-(D)Asp & 10 & (L)Ser-(L)Gln-(D)Gln \\
2 & (L)Asp-(L)Gln-(D)Asp & 11 & (L)Asn-(L)Asp-(L)Val \\
3 & (L)Leu-(L)Gln-(D)Asp & 12 & (L)Asn-(L)Asp-(L)Val \\
4 & (L)Leu-(L)Gln-(L)Val & 13 & (L)Asn-(L)Asp-(D)Asp \\
5 & (L)Leu-(L)Gln-(L)Phe & 14 & (D)Asn-(L)Pro-(D)Gln \\
6 & (L)Gln-(L)Gln-(L)Val & 15 & (L)Gln-(L)Pro-(D)Asp \\
7 & (L)Ser-(L)Gln-(D)Asp & 16 & (L)Asn-(L)Pro-(L)Phe \\
8 & (L)Leu-(L)Gln-(L)Phe & 17 & (L)Ala-(L)Ala-(L)Val \\
9 & (L)Leu-(L)Gln-(D)Gln & & \\
\hline
\end{tabular}

substrate binding cavities having the convergent hydrogen bonding donor/acceptors and the hydrophobic surfaces.

To examine the peptide-binding properties of receptor, $\mathbf{1}$ was screened against a tripeptide library on hydrophobic polystyrene in $\mathrm{CHCl}_{3} .{ }^{6}$ The library was prepared by encoded split synthesis and has the general structure Ac-AA3-AA2AA1- $\mathrm{NH}\left(\mathrm{CH}_{2}\right)_{6}-\mathrm{C}(\mathrm{O}) \mathrm{NH}-$ Polystyrene. ${ }^{7}$ Decoding the tripeptides on the colored beads by using electron capture gas chromatography revealed selective peptides-binding properties of macrocyclic compound (1). The most tightly binding substrates with macrocyclic compound (1) are shown in Table 1.

The binding data in Table 1 reveal a number of notable trends. First, high selectivity was observed for the residue in AA2 composed of (L)Gln (10/17). Second, selectivities were also found for AA1 and AA3 position. The substrates with (L)Leu (6 of 17) and (D)Asp (6 of 17) at AA2 and AA3 position were found to bind strongly.

To confirm the findings and to estimate the energetic extents of the selectivities observed, several peptides were resynthesized, and their association energy with $\mathbf{1}$ was measured in $\mathrm{CHCl}_{3}{ }^{8}$ The results are summarized in Table 2. These data showed that the most tightly bound peptides, Resin-(L)Leu-(L)Gln-(D)Asp-Ac was found to bind to $\mathbf{1}$ with $-6.0 \mathrm{kcal} / \mathrm{mol}$ binding energy. Removal of amide group in the side chain of substrate from (D)Asp and (L)Gln, to (D)Ala and (L)Ala at AA1 and AA2 sites reduce binding energy by 1.1 and $1.3 \mathrm{kcal} / \mathrm{mol}$, respectively. Also the change in the side-chain from leucine to alanine at AA3 site reduce the binding energies by $1.2 \mathrm{kcal} / \mathrm{mol}$. The binding energy with Polymer-(L)Ala-(L)Ala-(L)Ala-Ac was found to be both less than $-0.5 \mathrm{kcal} / \mathrm{mol}$. These data suggest that hydrogen bondings and hydrobobic interactions are crucial for complexation between receptor (1) and tripeptide sub-

Table 2. Binding Energy of Tripeptides to $\mathbf{1}$ in $\mathrm{CHCl}_{3}$

\begin{tabular}{cc}
\hline Peptide & Binding Energy $(\mathrm{kcal} / \mathrm{mol})$ \\
\hline Resin-(L)Leu-(L)Gln-(D)Asp-Ac & -6.0 \\
Polymer-(L)Leu-(L)Gln-(D)Ala-Ac & -4.9 \\
Polymer-(L)Leu-(L)Ala-(D)Asp-Ac & -4.7 \\
Polymer-(L)Ala-(L)Gln-(D)Asp-Ac & -4.8 \\
Polymer-(L)Ala-(L)Ala-(D)Ala-Ac & $<-0.5$ \\
\hline
\end{tabular}

strates.

In summary, cyclicpeptide receptor $\mathbf{1}$ have highly sequence-selective peptide binding properties. Further studies on peptide binding properties of the other related synthetic receptors are in progress in this laboratory.

\section{Experimental Section}

Synthesis of 3. To a solution of $0.86 \mathrm{~g}$ of $2(1.084 \mathrm{mmol})$ in $10 \mathrm{~mL}$ of THF and $2 \mathrm{~mL}$ of MeOH was added $44 \mathrm{mg}$ of $\mathrm{NaOH}(1.084 \mathrm{mmol})$ in $2 \mathrm{~mL}$ of $\mathrm{H}_{2} \mathrm{O}$ at room temperature. After stirring for $5 \mathrm{hr}$ at r.t., the reaction mixture was acidified with $1 \mathrm{~N} \mathrm{HCl}$ solution and extracted with EtOAc (3 $\times 50 \mathrm{~mL}$ ). The crude mono-carboxylic acid was dissolved in $10 \mathrm{~mL}$ of THF and $10 \mathrm{~mL}$ of methylene chloride, and then $0.4 \mathrm{~g}$ of pentafluorophenol $(2.17 \mathrm{mmol})$ and $0.42 \mathrm{~g}$ of EDC $(2.22 \mathrm{mmol})$ were added. After stirring for $8 \mathrm{hr}$ at r.t., all volatiles were removed at reduced pressure. The residue was purified by flash chromatography on silica gel using $1 / 1=$ EtOAc/Hexane to give the crude mono-pentafluorophenyl ester of $\mathbf{2}$ as an amorphous white solid.

To a solution of $1.83 \mathrm{~g}$ of the crude mono-pentafluorophenyl ester of $2(2.59 \mathrm{mmol})$ and $0.1 \mathrm{~mL}$ of anisole in $20 \mathrm{~mL}$ of methylene chloride was added $10 \mathrm{~mL}$ of TFA. After stirring for $4 \mathrm{~h}$ at r.t., all volatiles were removed at reduced pressure. The crude mono-pentafluorophenyl ester TFA salts of $\mathbf{2}$ were used the next reaction without further purification.

A solution of the crude pentafluorophenyl ester TFA salt ( $2.59 \mathrm{mmol})$ in $10 \mathrm{~mL}$ of DMA was added to a solution of $1.8 \mathrm{~mL}$ of DIPEA (10.36 mmol) in $250 \mathrm{~mL}$ of THF at room temperature for $20 \mathrm{hr}$ by syringe pump. After the stirring for $5 \mathrm{hr}$ at room temperature, all volatiles were removed at reduced pressure. The residue was purified by flash chromatography on silica gel using $10 \% \mathrm{MeOH}$ in methylene chloride to give $\mathbf{3}$ as an amorphous white solid (0.853 g, 78.0\%): ${ }^{1} \mathrm{H}$ NMR $\left(\mathrm{CDCl}_{3}\right) \delta(\mathrm{ppm}) 1.720$ (bs, 6H), $2.285(\mathrm{~m}, 2 \mathrm{H}), 3.247(\mathrm{~m}, 4 \mathrm{H}), 3.508(\mathrm{~m}, 2 \mathrm{H}), 3.716(\mathrm{~m}, 2 \mathrm{H})$, $3.836(\mathrm{~d}, 2 \mathrm{H}, J=7.5 \mathrm{~Hz}), 3.871(\mathrm{~s}, 6 \mathrm{H}), 4.651(\mathrm{~m}, 2 \mathrm{H})$, $7.256(\mathrm{~m}, 4 \mathrm{H}), 7.292-7.360(\mathrm{~m}, 6 \mathrm{H}), 7.683(\mathrm{~s}, 2 \mathrm{H}), 8.098(\mathrm{~s}$, $2 \mathrm{H}), 8.852(\mathrm{t}, 2 \mathrm{H}, J=2.0 \mathrm{~Hz}), 8.972(\mathrm{~s}, 2 \mathrm{H}), 10.302(\mathrm{~s}, 2 \mathrm{H})$; ${ }^{13} \mathrm{C}$ NMR $\left(\mathrm{CDCl}_{3}\right) \delta(\mathrm{ppm}) 22.368,30.702,38.244,46.921$, $53.190, \quad 56.052,62.889,122.946, \quad 124.415,127.109$, $128.426,129.882,130.101,131.677,132.486,135.984$, 140.094, 166.591, 167.032, 170.086, 172.334; MS (FAB) $\mathrm{m} / \mathrm{z} 843\left(\mathrm{MH}^{+}\right)$.

Synthesis of 1. To a solution of $0.74 \mathrm{~g}$ of $\mathbf{3}(0.879 \mathrm{mmol})$ in $10 \mathrm{~mL}$ of THF and $2 \mathrm{~mL}$ of MeOH was added $77 \mathrm{mg}$ of $\mathrm{NaOH}(1.934 \mathrm{mmol})$ in $2 \mathrm{~mL}$ of $\mathrm{H}_{2} \mathrm{O}$ at room temperature. After stirring for $5 \mathrm{hr}$ at r.t., the reaction mixture was acidified with $1 \mathrm{~N} \mathrm{HCl}$ solution and extracted with EtOAc (3 $\times 50 \mathrm{~mL}$ ). The crude dicarboxylic acid was dissolved in 10 $\mathrm{mL}$ of THF and $10 \mathrm{~mL}$ of methylene chloride, and then $0.356 \mathrm{~g}$ of pentafluorophenol $(1.934 \mathrm{mmol})$ and $0.371 \mathrm{~g}$ of EDC $(1.934 \mathrm{mmol})$ were added. After stirring for $8 \mathrm{hr}$ at r.t., all volatiles were removed at reduced pressure. The residue was purified by flash chromatography on silica gel using $1 / 1$ 
$=$ EtOAc/Hexane to give the crude bis-pentafluorophenyl ester of $\mathbf{3}$ as an as an amorphous white solid (0.513 g, $51 \%)$.

A solution of the crude bis-pentafluorophenyl ester of $\mathbf{3}$ $(0.448 \mathrm{mmol})$ and $0.418 \mathrm{~g}$ of $4(0.448 \mathrm{mmol})$ in $10 \mathrm{~mL}$ of DMA was added to a solution of $0.34 \mathrm{~mL}$ of DIPEA (2.4. $\mathrm{mmol}$ ) in $200 \mathrm{~mL}$ of THF at room temperature for $20 \mathrm{hr}$ by syringe pump. After the stirring for $5 \mathrm{hr}$ at room temperature, all volatiles were removed at reduced pressure. The residue was purified by flash chromatography on silica gel using $10 \% \mathrm{MeOH}$ in methylene chloride to give $\mathbf{1}$ as an amorphous red solid $(0.173 \mathrm{~g}, 32.0 \%)$ : ${ }^{1} \mathrm{H} \mathrm{NMR}\left(\mathrm{CDCl}_{3} /\right.$ $\left.\mathrm{CD}_{3} \mathrm{OD}\right) \delta(\mathrm{ppm}) 0.237(\mathrm{bs}, 4 \mathrm{H}), 1.316(\mathrm{t}, 6 \mathrm{H}, J=7.0 \mathrm{~Hz})$, $1.538(\mathrm{~m}, 8 \mathrm{H}), 2.275(\mathrm{~m}, 4 \mathrm{H}), 2.884(\mathrm{t}, 4 \mathrm{H}, J=12.0 \mathrm{~Hz})$, $3.080(\mathrm{~m}, 4 \mathrm{H}), 3.389(\mathrm{~m}, 4 \mathrm{H}), 3.660(\mathrm{~m}, 4 \mathrm{H}), 3.763(\mathrm{~m}, 4 \mathrm{H})$, $3.917(\mathrm{t}, 4 \mathrm{H}, J=5.5 \mathrm{~Hz}), 4.101(\mathrm{~d}, 4 \mathrm{H}, J=16.5 \mathrm{~Hz}), 4.200$ (d, 4H, $J=7.0 \mathrm{~Hz}), 4.267(\mathrm{t}, 4 \mathrm{H}, J=5.5 \mathrm{~Hz}), 4.559(\mathrm{~m}, 2 \mathrm{H})$, $5.213(\mathrm{~d}, 4 \mathrm{H}, J=16.0 \mathrm{~Hz}), 6.786(\mathrm{~s}, 4 \mathrm{H}), 6.880$ (d, 4H, $J=$ $9.5 \mathrm{~Hz}), 7.355(\mathrm{~m}, 10 \mathrm{H}), 7.537(\mathrm{~m}, 12 \mathrm{H}), 7.654(\mathrm{~s}, 4 \mathrm{H})$, $7.920(\mathrm{~m}, 8 \mathrm{H}), 8.326$ (d, 4H, $J=8.50 \mathrm{~Hz}), 8.450(\mathrm{~s}, 4 \mathrm{H})$, $8.882(\mathrm{~s}, 4 \mathrm{H}) ;{ }^{13} \mathrm{C} \mathrm{NMR}\left(\mathrm{CDCl}_{3} / \mathrm{CD}_{3} \mathrm{OD}\right) \delta(\mathrm{ppm}) 12.807$, $21.695,28.855,37.825,43.380,45.508,46.775,50.445$, $54.606, \quad 62.768,66.150, \quad 112.402, \quad 119.687, \quad 121.893$, $123.176,125.036,125.279,126.917,127.844,129.057$, $130.900,131.787,136.109,136.552,140.184,140.291$, $141.528,144.267,147.888,152.004,157.423,159.333$, 165.296, 170.019, 170.575, 172.745; IR (KBr) 3321.5, 3120.4, 2988.3, 1644.7, 1596.6, 1516.3, 1447.5, 1335.7, $1133.7 \mathrm{~cm}^{-1}$; UV $\left(\mathrm{CHCl}_{3}\right) 246,274,477 \mathrm{~nm}$; MS (FAB) $\mathrm{m} / \mathrm{z}$ $2454\left(\mathrm{MH}^{+}\right)$.

Acknowledgement. This work was supported by Korea Research Foundation (Grant No. 2000-015-DP0262).

\section{References}

1. Highlights in Bioorganic Chemistry; Schmuck, C.; Wennermers, H., Eds.; Wiley-VCH: New York, U. S. A. 2004; p 140; Wennemers, H. Chimia 2003, 57, 237; Still, W. C. Acc. Chem. Res. 1996, 29 , 155; Matteo, C.; Wennemers, H. J. Org. Chem. 2002, 67, 2696; Philipp, K.; Wennemers, H. Synlett 2005, 706; Lee, C.-Y.; Lee, K. H.; Yoon, S. S. Bull. Korean Chem. Soc. 2005, 26, 1843.

2. Deber, C. M.; Blout, E. B. J. Am. Chem. Soc. 1974, 96, 7566; Miyake, H.; Kojima, Y. Cood. Chem. Rev. 1996, 148, 301; Wudl, F.; Gaeta, F. J. J. Chem. Soc. Chem. Commun. 1972, 107.

3. Kubik, S.; Goddard, R. J. Org. Chem. 1999, 64, 9475; Kubik, S. J. Am. Chem. Soc. 1999, 121, 5846; Ishida, H.; Suga, M.; Donowaki, K.; Ohkubo, K. J. Org. Chem. 1995, 60, 5374; Leipert, D.; Nopper, D.; Bauser, M.; Gauglitz, G.; Jung, G. Angew. Chem. Int. Ed. Engl. 1998, 37, 3308.

4. Hartgerink, J. D.; Clark, T. D.; Ghadiri, M. R. Eur. J. Chem. 1998, 4, 1367.

5. Cram, D. J. Angew. Chem. Int. Ed. Engl. 1986, 25, 1093; Lehn, J.M. Angew. Chem. Int. Ed. Engl. 1988, 27, 89; Perderson, C. J. Angew. Chem. Int. Ed. Engl. 1988, 27, 1021.

6. Since 1 was sparingly soluble in $\mathrm{CDCl}_{3}$, it was not possible to study complexation properties of 1 in $\mathrm{CDCl}_{3}$ using NMR and thus solid phase color assay using encoded combinatorial substrate library is ideal to study the binding properties of 1 . See the related approach; Ohlmeyer, M. H. L.; Swanson, R. T.; Dillard, L. W.; Reader, J. C.; Asouline, G.; Kobayashi, R.; Wigler, M.; Still, W. C. Proc. Natl. Acad. Sci. USA 1993, 90, 10922; Borchardt, A.; Still, W. C. J. Am. Chem. Soc. 1994, 116, 373.

7. $\mathrm{AAn}=$ Any possible combinations of $25(\alpha)$-amino acids such as Gly, (L)Ala, (D)Ala, (L)Val, (D)Val, (L)Leu, (D)Leu, (L)Phe, (D)Phe, (L)Pro, (D)Pro, (L)Ser(OtBu), (D)Ser(OtBu), (L)Asp(OtBu), (D)Asp(OtBu), (L)Glu(OtBu), (D)Glu(OtBu), (L)Asn(Tr), (D)Asn(Tr), (L)Gln(Tr), (D)Gln(Tr), (L)Lys(Boc), (D)Lys(Boc), (L)His(Tr), (D)His(Tr). The number of members in substrates library is $(25)^{3}, 15625$. A total of 15 tag molecules (five tags for AAn) were used to encode the library according to the method reported in reference 6.

8. Yoon, S. S.; Still, W. C. Tetrahedron 1995, 51, 567. 